\title{
Nova sede do IEB e da Biblioteca Guita e José Mindlin - fala do Ministro Gilberto Gil
}

Em 07 de dezembro de 2006, na cerimônia de lançamento da pedra fundamental do edifício do projeto "Brasiliana USP", que abrigará num espaço conjunto a Biblioteca Guita e José Mindlin e o Instituto de Estudos Brasileiros, o Ministro de Estado da Cultura Gilberto Gil pronunciou o seguinte discurso:

Fico feliz em ver esta pedra cravada no chão sobre o qual se erguerá uma biblioteca. 0 prédio construído aqui não será apenas mais uma biblioteca, o que, por si só, já traria proveito a todos.

Estamos falando de uma coleção de livros que dá substância à palavra biblioteca, que dá sentido ao nome que se estampará na arquitetura, que faz esta palavra de origem latina soar mais familiar aos nossos ouvidos brasileiros.

Os que aqui futuramente pisarão estarão diante de páginas e papéis que deram seu corpo para a escrita de nossa história brasileira, que enriqueceram de variedade semântica a língua portuguesa, documentos mantidos por séculos, por muitas mãos cuidadosas, consumidos por olhos ativos em artes de decifração e que, depois de correrem mundo, foram recolhidos graciosamente por estes dois maravilhosos bibliófilos, Guita e José Mindlin.

A Coleção Brasiliana, que habitará essa nova casa, é um vasto material que será, por muitos séculos, uma referência para todos aqueles que buscam interpretar e imaginar a história de nosso País. Os livros desta biblioteca são obras que nos lembram o quão diversa foi, em cada tempo, nossa relação com nossas gentes, hábitos, sabedorias, costumes, conhecimentos e gostos. Sob as capas de cada livro há registros que iluminam nossos olhos com imagens de nós mesmos, visões sobre territórios e populações que se formaram em metamorfoses e miscigenações durante anos. Povos estrangeiros, brasílicos e brasileiros que constituíram o que hoje podemos observar na viva diversidade de nossa cultura.

Estamos aqui para marcar o ponto no qual a arquitetura disponibilizará espaço para leitores que emprestarão suas vozes ao patrimônio cultural. Que farão repercutir toda a imaterialidade de nosso patrimônio e darão um corpo de pesquisa para nossa diversidade. São essas tipografias múltiplas, plasmadas em livros, uma série de momentos da história desse objeto-livro, trazida do outro lado do Atlântico e que se estabeleceu entre nós. São detalhes e filigranas que pedem leituras atentas e en- 
tendimentos contemporâneos. Cada página deverá ser, futuramente, digitalizada e convertida em documentação virtual, para que todos os navegantes da rede possam ter acesso em qualquer lugar a este patrimônio comum.

Nós firmamos o compromisso do MinC e do Governo Federal com a tarefa de tradução dos documentos para o suporte eletrônico. Uma conversão que dará vida nova a esses documentos. Eles serão aqui ativados, para que as letras cantem seus sons e sotaques em todos os lugares onde o português é lido e falado neste planeta, despertando as falas eternamente ecoantes nas prateleiras silenciosas de cada estante.

Este prédio será um auditório contemporâneo, para todos os sentidos e inteligências. Será um laboratório dessa grande tecnologia que é o Livro, de suas tantas formas de o sentir e de o pensar se fazer letra, som, objeto gráfico, registro, memória e vida.

Os investimentos da Petrobras e do Ministério da Cultura já somam 5 milhões de Reais neste magnífico projeto. É a pequena contribuição que deve completar este gesto de enorme generosidade e dedicação à cultura. Há aqui uma perspectiva civilizatória de feições brasileiras - protagonizada por José e Guita Mindlin - que se encontra com instituições federais que foram fundadas no mesmo impulso de dotar o Brasil de uma cultura própria, de uma autonomia. Mas, para além dos recursos, acreditamos no significado transcendente que o lançamento simbólico desta pedra pode ter para a construção de uma política nacional de cultura. Imaginamos que as pesquisas e leituras, aqui empreendidas, também saiam dos muros dessa Universidade e se somem a outros espaços de nosso território, espaços nos quais o pensamento ganha contornos brasileiros, ao se dedicar aos objetos que se impregnaram de nossa cultura.

Esperamos que esta seja uma instituição nacional. Um centro nacional de referência para a pesquisa e reflexão sobre a nossa Nação, sobre seus muitos projetos de existência, sobre seus fracassos e ilusões, sobre suas possibilidades.

Esta biblioteca tem em seu gene a soma de muitos patrimônios. Todos eles aqui se encontrarão, na soma de muitos esforços: o de Mário de Andrade, o de Sérgio Buarque de Holanda e o de tantos outros, que viveram em busca de nossas tradições e singularidades.

Esta é uma ocasião na qual podemos olhar as realizações que fazem os sentidos despertarem entre nós e, a partir daí, podemos observar seu desenvolvimento e sua expansão em direção à consciência transformadora que devemos ter em relação ao nosso presente histórico.

Este é também o momento de refletir sobre nossas tentativas de gerar cidadania através da disponibilização de meios 
para que cada indivíduo possa trilhar seus próprios caminhos, se entregar à aventura do realmente novo, realizando sua pulsão vital de conhecer.

Essa construção solitária, que a leitura e a escrita espelham, é o que dá força ao projeto comum de todos os cidadãos. Quero dizer que não há Nação sem os indivíduos bem constituídos em sua autonomia, sem a liberdade e o juízo próprio, que caracterizam a emancipação para cada um. Cada vez mais, a reflexão e a inteligência devem ser os potenciais que podem nos guiar no processo de desenvolvimento, um processo que é de revolução criativa, de invenção de uma nova tecnologia humana sob os contornos da bio-política.

Só o investimento público e a igualdade de condições podem impulsionar os muitos homens que geram, com sua criatividade, um sistema de inovação dinamizador de nossa economia e sociedade. Precisamos enfrentar o debate sobre as restrições, ainda existentes para muitas populações excluídas da igualdade de direitos, como os povos negros, escravizados durante séculos e ainda hoje marginalizados, que lutam por cotas inclusivas nas universidades.

Muitos dos livros reunidos aqui são testemunhas e falas sobre essas populações, que são descritas, mas que não têm ainda sua própria voz. Há também registrada na tinta das impressões uma história nossa, que é de violência excludente. São documentos que nos dizem respeito, também naquilo que apontam para o passado não transposto, resíduos que fazem nosso presente problemático. Temos que construir instituições democráticas para que outras pessoas, gente como eu, como o grande intelectual Milton Santos, tenham sua palavra ouvida, sua contribuição reconhecida e valorizada.

As instituições que reúnem as muitas inteligências, como esta universidade, alimentam a nossa capacidade de produzir soluções para nossos problemas, que são muitos e complexos. Hoje, o Brasil precisa construir um projeto comum, consistente e adequado às condições efetivas de nossa sociedade e de nossa economia, sem aderir a modelos fáceis, disponíveis na ocasião, ou se prender a idéias fixas, que não nos deixam ver onde nos encontramos agora.

Criar espaços permanentes de releitura sobre nosso patrimônio simbólico, que possam atualizar referências e redispor valores e que dêem balizas ao pensamento contemporâneo: este é um gesto que repercutirá, inevitavelmente, em nosso futuro.

A tarefa que cabe ao Estado, nesse processo de gerar reflexão e pensamento crítico, é a de disponibilizar espaços e recursos do modo mais amplo possível, guiado por princípios republicanos e democráticos. 0 Governo deve criar meios ade- 
quados para que os mais distintos atores sociais possam efetuar, por si mesmos, a necessária construção de perspectivas estratégicas para o País.

Essas perspectivas futuras estão baseadas, também, na capacidade de interpretação da nossa realidade, como ela foi gerada até aqui, como chegamos ao que somos agora.

A biblioteca a ser construída no campus da USP será um desses espaços vitais para a prospecção histórica e para a formulação estratégica de gerações. Sem dúvida, este será um ambiente intelectual que abrirá caminhos daqui para diante.

0 Ministério da Cultura está voltado para essa biblioteca, disposto a criar, junto com a comunidade universitária e o MEC, um instituto de formação de consciência crítica, que lance luzes sobre a cultura, que afirme sua importância e seu lugar central, como nos dizia o ministro Celso Furtado, no desenvolvimento social e econômico do País. Penso que aqui consolida-se hoje uma das responsabilidades intransferiveis do Estado brasileiro: a missão de fazer com que a cultura e a educação sejam vetores fundamentais de nosso desenvolvimento.

Nosso ideal de Estado é muito diferente daqueles dois modelos que se enfrentaram como antagônicos nas últimas décadas, o Estado máximo e o Estado mínimo. Pensamos um Estado que deve servir à desobstrução e geração de fluxos vivos, que abra os caminhos institucionais para as forças vitais e produtivas de nossa sociedade, que seja poroso aos sistemas de inovação e atualização. Uma instituição que deve ser capaz de rearticular, através de cada ação sua, os diversos campos nos quais, fatalmente, acabamos por dividir a cultura, por necessidades administrativas.

Estas ações nos levam para perto de um ideal de cultura que é o ideal de diálogo, interpenetração e supressão de fronteiras ilusórias.

Estamos aqui reunidos, o Ministério da Cultura, o Ministério da Educação, a Universidade de São Paulo e um de seus mais importantes centros de pesquisa e reflexão, arquivo e museologia, o Instituto de Estudos Brasileiros, para construir uma instituição que redimensione, constantemente, nossas noções de Cultura. É uma reunião tão importante, concreta e simbolicamente, que todos estamos comovidos e otimistas quanto ao sucesso e ao resultado deste compromisso de todos nós com a ousadia nas politicas culturais do País.

Eu saúdo e parabenizo a todos os que estão ao nosso lado, todos que empenharão, por anos, seus trabalhos e comprometimentos. 